\title{
Native Mycorrhizal Fungi in Land Contaminated Cr, Co and $\mathrm{Cu}$
}

\author{
Muhammad Akhsan Akib1*, Andi Nuddin², Retno Prayudyaningsih', Syatrawati", \\ Henny Setiawaty ${ }^{5}$, Nasir Sennaini ${ }^{5}$, Suherman ${ }^{2}$
}

1 Department of Agrotechnology, Faculty of Agriculture, Animal Husbandry and Fishery; and Department of Biology Education, Faculty of Teacher Training and Education, Universitas Muhammadiyah Parepare, Indonesia.

2 Department of Agrotechnology, Faculty of Agriculture, Animal Husbandry and Fishery, Universitas Muhammadiyah Parepare, Indonesia.

3 Environment and Forestry Research and Development Institute of Makassar, Indonesia.

4 Department of Plantation, Polytechnic of Pangkep State Agricultural, South Sulawesi, Indonesia.

${ }_{5}^{5}$ Faculty of Teacher Training and Education, Universitas Muhammadiyah Parepare, Indonesia.

*Corresponding author's e-mail: akhsanbagus@umpar.ac.id

How to Cite: Akib, M.A., Nuddin, A., Prayudyaningsih, R., Syatrawati., Setiawaty, H., Sennaini, N., Suherman. (2019). Native Mycorrhizal Fungi in Land Contaminated Cr, Co and Cu. Int. J. Agr. Syst. 7(2): 116-126

\begin{abstract}
Mycorrhizal fungi that are capable of adapting and resistant to heavy metal contaminated environments have received special attention for phytorhizoremediation researchers. The aim of the study was to explore native mycorrhizal fungi from areas contaminated with heavy metals to be used as starter biological agents in the phytorhizoremediation program. This research was carried out in two phases, i.e. rhizosphere sampling of Polypodium glycyrrhiza, Sumasang sp (local name) and Spathoglottis plicata at coordinates 2031'57,6"S and 121022'50,7"E. Rhizosphere of Chromolaena odorata, Melastama affine and Nephrolepis exaltata at coordinates 2031'53,5"S and 121022'35,4"E, Sorowako, Indonesia; While the other phase is isolating and identifying mycorrhizal spores in the Microbiology Laboratory, Research and Development Center for Environment and Forestry in Makassar, Indonesia. The results showed that be discovered three genus of mycorrhizal fungi were able to adapt and resistant in areas contaminated with $\mathrm{Cr}, \mathrm{Co}$, and $\mathrm{Cu}$, i.e. $44.44 \%$ to $75.86 \%$ Acaulospora sp; $9.52 \%$ to $44.44 \%$ Gigaspora sp, and $3.38 \%$ to $19.05 \%$ Glomus sp. which could be used as source of inoculum in Phyto-rhizoremediation program. We recommend using native mycorrhizal fungi combined with endemic plant of location to rehabilitation heavy metal contaminated soils.
\end{abstract}

Copyright $\odot 2019$ IJAS. All rights reserved.

Keywords:

Acaulospora; fungi; heavymetal; postmine; phytorhizoremediation. 


\section{Introduction}

Arbuscula mycorrhiza has a very important role in soils contaminated with heavy metals, this is because arbuscula mycorrhiza associated with plant roots is known to play a role in rehabilitating lands contaminated with heavy metals (Asmelash et al, 2016). The mechanism of protection provided by arbuscula mycorrhizae against heavy metals and toxic elements can be through the effects of filtration (Bano and Ashfaq, 2013), accumulation of heavy metals into hyphae (Ferrol et al, 2016), deactivate chemically (Abu-Elsaoud et al, 2017) or mechanism of decomposition of heavy metals by secretion of external hyphal (Gong and Tian, 2019).

Concentration of heavy metals that exceed the threshold becomes a source of pollutants in post-mining land. Heavy metal pollution has occurred in post-mining areas of gold (Fashola et al, 2016), nickel (Hu et al, 2017), tin (Kurniawan, 2017) and coal (Bhuiyan et al, 2010). High concentrations of heavy metals will inhibit growth (Jaishankar et al, 2014), change morphology (Bini et al, 2012) and disrupts organism's metabolism (Singh et al, 2012). However, each type of organism also has a defense strategy against heavy metal pressure to carry out the adaptation process (Emamverdian et al, 2015).

Heavy metals can cause changes in the community of microorganisms, so microorganisms are more resistant to pressure from heavy metals (Igiri et al, 2018), essential and non-essential heavy metals show toxicity if they are above a certain concentration (Bansal and Asthana, 2018). This stress toxicity is limited by the threshold value (Ju et al. 2016), which varies depending on many factors, including the type of microorganism, physicochemical properties and metal concentration, and soil conditions (edafic) and the environment (Emamverdian et al, 2015).

Mycorrhizal fungi are one of the obligatory soil microorganisms. These fungi have ability mutualistic symbiosis with $80 \%$ of plant species (Berruti et al, 2016). However, very determined by the type of mycorrhizal fungi, plant species and environmental conditions (Tahat and Sijam, 2012). Mycorrhizal fungi which have extensive adaptability, will have the ability to survive in variety of environmental conditions, especially in soils contaminated with heavy metals (Chen et al, 2018). However, the tolerance level of heavy metals varies between various groups of fungi (Anahid et al, 2011). Several strains of mycorrhizal fungi can tolerate heavy metal stresses, including, Glomus intraradices, Glomus mosseae and several other important Glomus species. Therefore, the selection of mycorrhizal fungi that are tolerant of heavy metals is an important step in obtaining healthy plants in areas contaminated with heavy metals (Bano and Ashfaq, 2013).

Evaluating the tolerance of microorganisms in soil contaminated with heavy metals, specialists have adopted the concept of community tolerance caused by pollutants (Giller et al, 2009). This perspective establishes that over time, in an ecosystem, exposure to heavy metal contamination increases tolerance to the community of microorganisms (Shade et al, 2012). Tiwari and Lata (2018) showing that long-term exposure heavy metals in puts pressure on soil microbes and increases tolerance. They concluded that the long-term accumulation of heavy metals in the soil gave the time to community of microorganisms to adapt to heavy metals. This adaptation has been linked to two factors, namely, the gradual decline in metal availability due to the immobilization reaction that occurs in the rhizosphere, while another factor is the gradual change in microbial community structure, based on changes in phospholipid fatty acid profiles (Azarbad et al, 2013) that produce organisms that are more tolerant. 
In addition to these two things, mycorrhizal fungi such as organisms accumulate heavy metals in vesicles, hyphae, and arbuscula fungi (Rezvani et al, 2015).

Native mycorrhizal fungi isolate that have been adapt to environments that have abiotic stress can be potential biotechnology tools to be inoculated in plants for the successful restoration of degraded ecosystems. This needed because some rehabilitation activities land which contaminated with heavy metals, using non-native mycorrhizal fungi so that association of plant roots and mycorrhizal fungi becomes inhibited. So that an activity is needed that aims to explore indigenous mycorrhizal fungi from areas contaminated with heavy metals to be used as a starter for biological agents.

\section{Materials and Methods}

The study was conducted in two phases. First phase, the taking rhizosphere of Polypodium glycyrrhiza, Sumasang sp (local name) and Spathoglottis plicata at coordinates 2031'57,6 "S; 121022'50,7" E. Rhizosphere of Chromolaena odorata, Melastama affine and Nephrolepis exaltata at coordinates 2031'53,5 "S; 121022'35,4" E, Sorowako, Indonesia. Using method from Krishnamoorthy (2015) and Toh et al (2018). Another phase, mycorrhizal fungi spores in isolated from host plant of rhizosphere followed wet sieving techniques (Brundrett et.al, 1984) using multilevel sieves (mess size of 325, 40 and $50 \mu \mathrm{m}$ ) in Microbiology Laboratory, Center for Research and Development for Environment and Forestry, Makassar, Indonesia. Spore morphology was identified using a manual from International Culture Collection of Vesicular Arbuscular Mycorrhizal Fungi (INVAM, 2019)

Concentration of soil heavy metals was measured while in laboratory of chemistry, Polytechnic of Ujung Pandang, Makassar, using manual book of X-Ray Florence Spectrophotometer/Bruker/S2 Ranger, Heavy metal concentration in soil can be seen in table 1. The coordinate determination of host plant rhizosphere taking location was determined using the Global Positioning System (GPS) Coordinates Finder (Figure 1).

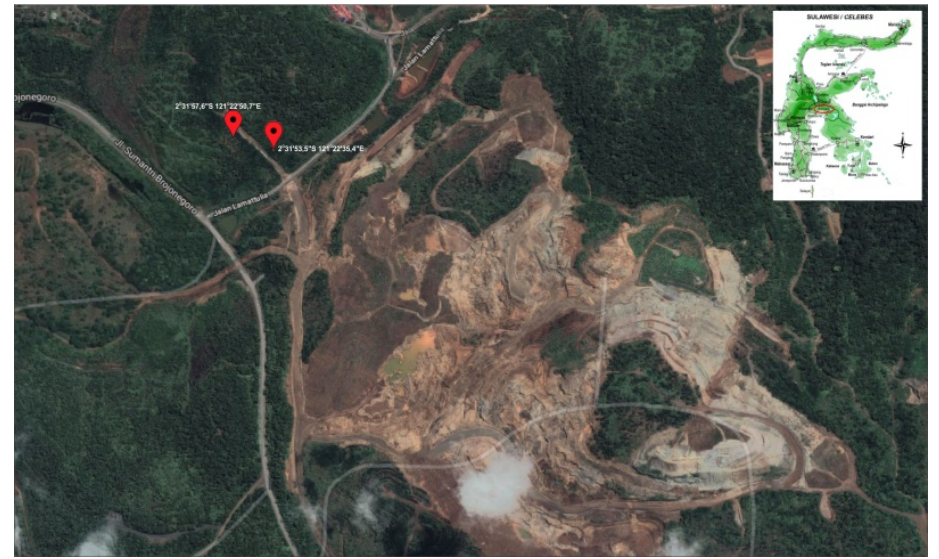

Figure 1. Location of rhizosphere taking of host plants on land contaminated $\mathrm{Cr}, \mathrm{Co}$ and $\mathrm{Cd}$.

\section{Results and Discussion}

Laboratory test results show that post-mining land has been contaminated with $\mathrm{Cr}, \mathrm{Co}$, and $\mathrm{Cu}$ metals which exceed the critical limit for soil and plants (Table 1), this will give stress to macroorganisms and soil microorganisms to complete their life cycle, but 
some organisms are able to adapt and tolerant to the environment contaminated with the metal.

Table 1 Elements of heavy metals in land contaminated with heavy metals in Sorowako, East Luwu district, South Sulawesi, Indonesia.

\begin{tabular}{lcccc}
\hline \multicolumn{1}{c}{ Heavy metal } & \multicolumn{2}{c}{ Coordinat } & \multicolumn{2}{c}{ Critical limit } \\
\hline \multicolumn{1}{c}{$(\mathbf{p p m})$} & $2^{\mathrm{O}} 31^{\prime} 57,6^{\prime \prime} \mathrm{S}$ & $2^{\mathrm{O}} 31^{\prime} 53,5^{\prime \prime} \mathrm{S}$ & Soil & Plant \\
\hline Chrome $(\mathbf{C r})$ & $121^{\circ} 22^{\prime} 50,7^{\prime \prime} \mathrm{E}$ & $121^{\circ} 22^{\prime} 35,4^{\prime \prime} \mathrm{E}$ & & \\
Cobal $(\mathbf{C o})$ & 26.458 & 38.754 & $2,5^{*}$ & $5-30^{* *}$ \\
Copper $(\mathbf{C u})$ & 1.578 & 3.005 & $10^{*}$ & $15-30^{* *}$ \\
\hline
\end{tabular}

Source: *Ministry of State for Population and Environment Republic of Indonesia and Dalhousie University Canada. 1992; **Alloway (1995) and Shanab et al (2007).

A series of "classical" ecological principles that examine the process of increasing tolerance or resistance of microorganism community have been widely studied. The microorganism resistance, refers to the ability to resist the effects of pollutants which are usually effective against them, while microorganism resistance, refers to the ability to adapt to persistent pollutants (Bhalerao, 2013). Tiwari and Lata (2018) suggest that tolerance and resistance to the toxic effects of heavy metals depend on the mechanisms involved. In short, tolerance to heavy metals can be defined as a phenomenon where resistance microorganisms increase to again heavy metal stress which can lead to poisoning.

All organism, including microorganism, can achieve resistance to heavy metals by "avoidance" when organisms are able to limit metal absorption, or by "tolerance" when organisms survive in high internal metal concentration (Hossain et al, 2012; Khare et al, 2017; Ojuederie and Babalola, 2017). The first mechanism involved is reduced absorption or increase in efflux, formation and release of organic acids outside the cell complex. The second mechanism, metal is chelated intracellularly through the synthesis of ligands such as metallothionein, polyphosphate, and / or compartments in vacuoles (Ma et al, 2016; Singh et al, 2016). Individuals who are tolerant and sensitive to heavy metals can be distinguished by their growth performance on substrates contaminated with heavy metals (Glubiak et al, 2012, Singh et al. 2016).

Identification result of native mycorrhizal fungi spore obtained from various rhizosphere of host plants in land contaminated with heavy metals, were found three genera of mycorrhizal fungi spore that were adaptable and resistant in land with high concentrations of heavy metals, i.e. Acaulospora sp, Gigaspora sp and Glomus sp (Figure 2). Adaptability and resistance of fungi, possibly following the mechanism of metal chelating processes intracellularly through the synthesis of ligands such as metallothionein, polyphosphate, and / or compartments in vacuoles so that become tolerant. 


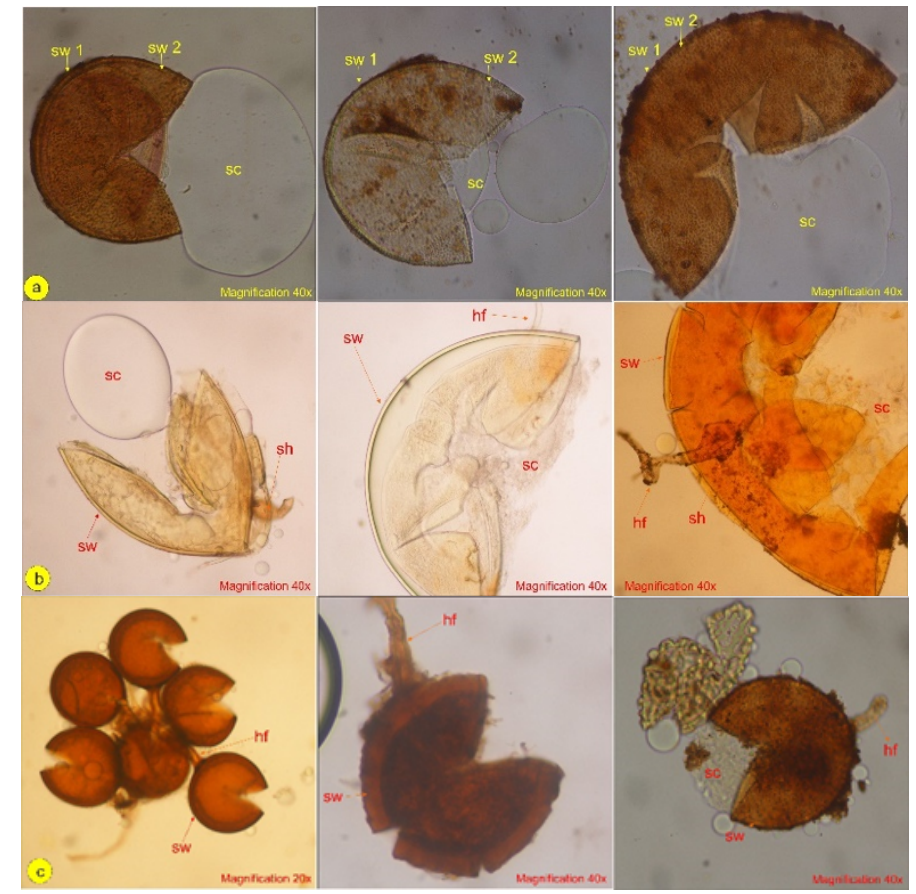

Figure 2. Morphology of native mycorrhizal fungi spores isolated from land contaminated with heavy metals. (a) Acaulospora sp., (b) Gigaspora sp., and (c) Glomus sp.

Glomus sp. is the genus mycorrhizal from family Glomeraceae. Some of the characteristics of this genus are spores formed singly or in pairs in the terminals of the nongamethangium hyphae which are undifferentiated in the sporocarp. When the adult spores are separated from the adhesive hyphae by a partition. Spores are globose, sub-globose, ovoid, or obovoid with spore walls consisting of more than one layer, hyaline to yellow, brownish, brown, and black, measuring between 20 - $400 \mu \mathrm{m}$ (Lone et al, 2014; INVAM 2019).

Acaulospora sp. is the genus mycorrhizal which belongs to the family of Acaulosporaceae. This genus has several characteristics including having 2-3 spore walls, spores are formed on the side of the sporiferous saccule neck, shaped spores of globose up to ellipse, colored hyaline, yellow, or yellow red, measuring between 100$400 \mu \mathrm{m}$ (Leno et al, 2014; INVAM 2019).

Gigasporaceae is a family of mycorrhiza which belongs to the genus Gigaspora sp. This genus has a characteristic, that is, spores are produced singly in the soil, spore do not have a inner layer wall, be found of bulbous suspensor, shaped of globose or subglobose, colored of cream to yellow, size spore 125-600 $\mu \mathrm{m}$ (Leno et al, 2014 ; INVAM 2019).

Germination and formation process of mycorrhizal fungi spore, through 3 stages, i.e, (1) germination of spores in the soil, (2) penetration of hyphae into root cells and (3) development of hyphae in the root cortex (Pereira et al. 2015), and these third of stages possibility also be carried out by mycorrhizal fungi in the land contaminated heavy metals in to multiply themselves. The calculation results of the number of mycorrhizal fungi spores in $100 \mathrm{gr}$ of heavy metals contaminated rhizosphere found in different amounts and dominated by the genus Acaulospora sp. (Table 2). This allegedly due beside to heavy metal stresses, also influenced by other abiotic factors. According to Jamiołkowska et al (2018) that abiotic factors which determine the abundance and 
development of mycorrhizal fungi spores among other temperature, $\mathrm{pH}$, soil organic matter and soil water content.

Optimum soil temperature for germination of mycorrhizal fungi spores is very diverse and depends on the type. The best temperature for the development of mycorrhizal fungi is at ambient temperature of $30^{\circ} \mathrm{C}$ but for the best colonization of mycelia is at ambient temperature $28^{\circ} \mathrm{C}-35^{\circ} \mathrm{C}$ (Sight, 2004). Gigaspora sp can grow and germinate well at ambient temperatures of $25^{\circ} \mathrm{C}-35^{\circ} \mathrm{C}$ while Glomus mosseae originates from cooler regions. The best germination is ambient temperature $18^{\circ} \mathrm{C}-20^{\circ} \mathrm{C}$. Some scientific literature also suggests that colonization of plant roots by mycorrhizal fungi still occurs at soil temperatures as low as $5^{\circ} \mathrm{C}$ (Gavito and Aguilar, 2012).

Fungi are generally more resistant to changes in soil $\mathrm{pH}$. However, the adaptability of each species of mycorrhizal fungi to soil $\mathrm{pH}$ varies greatly. Soil $\mathrm{pH}$ can also affect germination, development, and role of mycorrhiza to plant growth. The optimum $\mathrm{pH}$ for development of mycorrhizal fungi is ranging from $\mathrm{pH}$ 5.6-7 for Glomus sp. $\mathrm{pH}$ 4-6 for Gigaspora sp. pH 4-5 for Acaulospora sp, (Setiadi and Setiawan, 2011). According to Bertham (2003) Glomus mosseae usually in alkaline soils can germinate well at pH 6-9. Gigaspora corallodea and G. heterogama of more acidic species can germinate well at $\mathrm{pH}$ 4-6.

Soil organic matters also play a role in increasing the number of mycorrhizal fungi spores. The maximum number of spores found in soils containing organic material from 1 to 2 percent, while in soils containing organic matter less than 0.5 percent number of spores found is very low (Holste, et al. 2016).

Groundwater content also affects germination and the period of dormancy of mycorrhizal fungal spores. in wet soil, the dormancy period for Glomus sp and Gigaspora sp spores is longer than in dry soil. Whereas for Acaulospora sp spores the period of dormancy is generally not affected by soil water content (Tommerup, 1983; Juge et al, 2002).

Table 2. Number of mycorrhizal fungi spores per $1000 \mathrm{mg}$ of rhizosphere samples

\begin{tabular}{|c|c|c|c|c|c|}
\hline \multirow{2}{*}{ Coordinate } & \multirow{2}{*}{ Family } & \multirow{2}{*}{ Hots Plant Rhizosphere } & \multicolumn{3}{|c|}{ Number of Spora } \\
\hline & & & GL & GS & $\mathrm{AC}$ \\
\hline \multirow{3}{*}{$\begin{array}{c}2 \mathrm{O} 31^{\prime} 57,6^{\prime \prime} \mathrm{S} \\
121^{\circ} 22^{\prime} 50,7^{\prime \prime} \mathrm{E}\end{array}$} & Polypodiaceae & Polypodium glycyrrhiza & 2 & 0 & 7 \\
\hline & & Sumasang sp (local name) & 2 & 2 & 8 \\
\hline & Orchidaceae & Spathoglottis plicata & 0 & 1 & 1 \\
\hline \multirow{3}{*}{$\begin{array}{c}2031^{\prime} 53,5^{\prime \prime} \mathrm{S} \\
121^{\circ} 22^{\prime} 35,4^{\prime \prime} \mathrm{E}\end{array}$} & Asteraceae & Chromolaena odorata & 0 & 0 & 24 \\
\hline & Melastomataceae & Melastama affine & 0 & 1 & 1 \\
\hline & Nephrolepidaceae & Nephrolepis exaltata & 0 & 0 & 13 \\
\hline
\end{tabular}

Note: GL, Glomus sp; GS, Gigaspora sp; AC, Acaulospora sp

Mycorrhizal fungi are very important in the heavy metal phytostabilization program that exceeds the critical limit. Plants that have been symbiosis with mycorrhizal fungi accumulate and store heavy metals in vesicles and hyphae of fungi on their roots, so that metal pollutants do not move and do not inhibit the growth and absorption of phosphorus and other micronutrients (Bano, 2013; Yang, 2016). Mycorrhizal fungi also release various organic acids which increase the solubility of phosphate compounds which are insoluble in soil (Bolduc dan Hijri, 2010; Johri et al, 2015; Jamal et al, 2018). Mycorrhizal fungi release glomalin which is a particular sorble metal glycoprotein that increases immobilization of toxic metals (Ambrosini, 2015; Hristozkova et al, 2016). The 
metallothionein protein released by certain mycorrhizal fungi, also reduces the toxicity of heavy metals in the soil (Bano dan Ashfaq, 2013). Certain external mycorrhizal myceliums also produce a type of protein called glycoprotein (Glomalin), which has a heavy metal binding area. (Trouvelot et al, 2015; Leal et al, 2016).

Several reports and reviews show that mycorrhizal from areas contaminated with heavy metals has developed tolerance to heavy metal toxicity and adapted well. Mycorrhizal has been proven to evolve tolerance to heavy metals, as stated by Lingua et al (2012) and French (2017), Some strains of mycorrhizal fungi tolerant develop in one or two years. However, to date, the potential interaction mechanism between mycorrhizal fungi and heavy metal, as well as cellular and molecular mechanisms about the tolerance of heavy metals by mycorrhizal fungi, is still poorly understood. Because mycorrhizal fungi cannot be cultivated without host plant, so more difficult to showed absorption of metals intrinsically by hyphae.

Isolate of native mycorrhizal fungi in area contaminated of heavy metals is more tolerant than isolate from non-polluted area, and it has been reported that native mycorrhizal fungi efficiently affect plant root growth in heavy metal stressed environments (Upadhyaya et al, 2010; Vaishaly et al, 2015; Burreti, et al, 2015). Thus, it is important to sieve native isolate that tolerant of heavy metal for ensure the effectiveness of symbiosis between mycorrhizal fungi and plant roots at area recovery programs contaminated heavy metal. Furthermore, suggested that phytoremediation potential for contaminated area can be increased by inoculated of hyperaccumulator plant roots with mycorrhizal fungi which are most suitable for contaminated sites. Therefore, very important for combine endemic plants with isolate of indigenous mycorrhizal fungi that adjusted for the type and concentration of heavy metals in future studies for the Phyto-rhizoremediation program.

\section{Conclusion}

The found three genus of native mycorrhizal fungi that ablel to adapt in area contaminated $\mathrm{Cr}, \mathrm{Co}$, and $\mathrm{Cu}$ which could be used as source of inoculum in Phytorhizoremediation program, we recommend for use native mycorrhizal fungi which combined with endemic plants of locations for more successful work in rehabilitating heavy metal contaminated soil.

\section{Acknowledgements}

Author thanks to Ministry of Research, Technology and Higher Education of the Republic of Indonesia has provided support through basic research competition in 2019.

\section{References}

Abu-Elsaoud, A. M., N. A. Nafady., A. M. Abdel-Azeem. (2017). Arbuscular mycorrhizal strategy for zinc mycoremediation and diminished translocation to shoots and grains in wheat. PLoS ONE 12(11): e0188220

Alice, R. B. and M. Hijri. (2010). The Use of Mycorrhizae to Enhance Phosphorus Uptake: A Way Out the Phosphorus Crisis. J Biofertil Biopestici, 2: 1-5.

Alloway, B. J. (1995). Heavy Metals in Soils. Blackie Academic and Professional, London, UK, 2nd edition. 
Ambrosini, V. G., J. G. Voges., L. Canton., R. R. Couto., P. A. A. Ferreira., J. J. Comin., G. W. B. Melo., G. Brunetto., C. R. F. S. Soares. (2015). Effect of arbuscular mycorrhizal fungi on young vines in copper-contaminated soil. Braz J Microbiol. 46(2): 1045-1052.

Anahid, S., S. Yaghmaei., Z. Ghobadinejad. (2011). Heavy metal tolerance of fungi. Scientia Iranica, 18(3): 502-508.

Asmelash, F., T. Bekele., E. Birhane. (2016). The potential role of arbuscular mycorrhizal fungi in the restoration of degraded lands. Front. Microbiol. 7:1095.

Azarbad, H., M. Niklinska., C. A. M. Gestel., N. M. Straalen., W. F. M. Roling., R. Laskowski. (2013). Microbial community structure and functioning along metal pollution gradients. Environmental Toxicology and Chemistry, 32(9): 1992-2002.

Bano, S. A. and A. D. Ashfaq. (2013). Role of mycorrhiza to reduce heavy metal stress. Natural Science, 5(12A): 16-20.

Bansal, S. L., and S. Asthana. (2018). Biologically Essential and Non-Essential Elements Causing Toxicity in Environment. J Environ Anal Toxicol, 8(2): 557-562.

Berruti, A., E. Lumini., R. Balestrini., V. Bianciotto. (2015). Arbuscular Mycorrhizal Fungi as Natural Biofertilizers: Let's Benefit from Past Successes. Front Microbiol. 6: 1559.

Bertham, R. Y. H. (2003). Purification techniques of monoxenic VAM culture using petridisk and test tube methods. Jurnal Ilmu-ilmu Pertanian Indonesia, 5(1): 1826.

Bhalerao, S. A. (2013). Arbuscular Mycorrhizal Fungi: A Potential Biotechnological Tool for Phytoremediation of Heavy Metal Contaminated Soils. International Journal of Science and Nature. 4(1): 1-15.

Bhuiyana, M. A. H., L. Parvez., L. A. Islam., S. B. Dampare., S. Suzuki. (2010). Heavy metal pollution of coal mine-affected agricultural soils in the northern part of Bangladesh. Journal of Hazardous Materials, 173(1-3): 384-392.

Bini, C., M. Wahsha., S. Fontana., L. Maleci. (2012). Effects of heavy metals on morphological characteristics of Taraxacum officinale Web growing on mine soils in NE Italy. Journal of Geochemical Exploration, 123: 101-108.

Brundrett, M. C., Y. Piche., R. L. Peterson. (1984). A new method for observing the morphology of vesicular-arbuscular mycorrhizae. Canadian Journal of Botany 62(10):2128-2134.

Chen, M., M. Arato., L. Borghi., E. Nouri., D. Reinhardt. (2018). Beneficial Services of Arbuscular Mycorrhizal Fungi - From Ecology to Application. Front Plant Sci. 9: 1270.

Emamverdian, A., Y. Ding., F. Mokhberdoran., Y. Xie. (2015). Heavy Metal Stress and Some Mechanisms of Plant Defense Response. Hindawi Publishing Corporation the Scientific World Journal, Article ID 756120: 1-18.

Fashola, M. O., V. M. N. Jame., O. O. Babalola. (2016). Heavy Metal Pollution from Gold Mines: Environmental Effects and Bacterial Strategies for Resistance. Int. J. Environ. Res. Public Health, 13: 1047-1067.

Ferrol, N., E. Tamayo., P. Vargas. (2016). The heavy metal paradox in arbuscular mycorrhizas: from mechanisms to biotechnological applications. Journal of Experimental Botany. 67(22): 6253-6265.

French, K. E. (2017). Engineering Mycorrhizal Symbioses to Alter Plant Metabolism and Improve Crop Health. Front Microbiol. 8: 1403.

Gavito, M. G. and C. A. Aguilar. (2012). Temperature stress in arbuscular mycorrhizal fungi: a test for adaptation to soil temperature in three isolates of Funneliformis mosseae from different climates. Agricultural and Food Science. 12(1): 2-11. 
Glubiak, E. S., J. Korzeniowska., A. Kocon. (2012). Effect of the Reclamation of Heavy MetalContaminated Soil on Growth of Energy Willow. Pol. J. Environ. Stud. 21(1):187-192.

Holste. E. K., K. D. Holl., R. A. Zahawi., R. K. Kobe. (2016). Reduced aboveground tree growth associated with higher arbuscular mycorrhizal fungal diversity in tropical forest restoration. Ecology and Evolution 6(20): 7253-7262.

Hossain, M. A., P. Piyatida., J. A. T. Silva., M. Fujita. (2012). Molecular Mechanism of Heavy Metal Toxicity and Tolerance in Plants: Central Role of Glutathione in Detoxification of Reactive Oxygen Species and Methylglyoxal and in Heavy Metal Chelation. Journal of Botany, Article ID 872875, 37 pages.

Hristozkova, M., M. O. Geneva., I. Stancheva., M. Boychinova., E. Djonova. (2016). Contribution of arbuscular mycorrhizal fungi in attenuation of heavy metal impact on Calendula officinalis development. Applied Soil Ecology. 101:57-63.

Hu, B., X. Jia., J. Hu., D. Xu., F. Xia., Y. Li. (2017). Assessment of Heavy Metal Pollution and Health Risks in the Soil-Plant-Human System in the Yangtze River Delta, China. Int. J. Environ. Res. Public Health, 14: 1042-1062.

Igiri, B. E., S. I. R. Okoduwa., G. O. Idoko., E. P. Akabuogu., A. O. Adeyi., I. K. Ejiogu. (2018). Toxicity and Bioremediation of Heavy Metals Contaminated Ecosystem from Tannery Wastewater: A Review. Journal of Toxicology, Article ID 2568038: 1- 16.

INVAM, (2019). International Culture Collection of Vesicular Arbuscular Mycorrhizal Fungi. http://invam.caf.wvu.edu.

Jaishankar, M., T. Tseten., N. Anbalagan., B. B. Mathew., K. N. Beeregowda. (2014). Toxicity, mechanism and health effects of some heavy metals. Interdiscip Toxicol. 7(2): 60-72.

Jamal, A., A. Khan., M. Sharif., H. Jamal. (2018). Application of Different Organic Acids on Phosphorus Solubility from Rock Phosphate. Journal of Horticulture and Plant Research. 2: 43-48.

Jamiołkowska, A., A. Ksiezniak., A. Gałazka., B. Hetman., M. Kopacki., B. S. Bednarz. (2018). Impact of abiotic factors on development of the community of arbuscular mycorrhizal fungi in the soil: A Review. Int. Agrophys. 32, 133-140.

Johri, A. K., R. Oelmuller., M. Dua., V. Yadav., M. Kumar., N. Tuteja., A. Varma., P. Bonfante., B. L. Persson., R. M. Stroud. (2015). Fungal association and utilization of phosphate by plants: success, limitations, and future prospects. Front Microbiol. 6: 984.

Ju, J. H., E. Y. Choi., Y. H. Yoon. (2016). A Pilot Study to Determine the Substrate Threshold Ffr Heavy Metal Toxicity in Groundcover Plants Used in Urban Landscapes. Applied Ecology and Environmental Research, 14: 59-70.

Juge, C., J. Samson., C. Bastien., H. Vierheilig., A. Coughlan., Y. Piche. (2002). Breaking dormancy in spores of the arbuscular mycorrhizal fungus Glomus intraradices: a critical cold-storage period. Mycorrhiza 12:37-42.

Ken, E. G., E. Witter., S. P. Mcgrath. (2009). Heavy metals and soil microbes. Soil Biology and Biochemistry, 41(10): 2031-2037.

Khare, D., N. Mitsuda., S. Lee., W. Y. Song., D. Hwang., M. O. Takagi., E. Martinoia., Y. Lee., J. U. Hwang. (2017). Root avoidance of toxic metals requires the GeBP-LIKE 4 transcription factor in Arabidopsis thaliana. New Phytol. 213(3): 1257-1273.

Krishnamoorthy R., C. G. Kim., P. Subramanian., K. Y. Kim., S. Gopal., T. Sa. (2015). Arbuscular Mycorrhizal Fungi Community Structure, Abundance and Species Richness Changes in Soil by Different Levels of Heavy Metal and Metalloid Concentration. PLoS ONE 10(6): 1-15. 
Kurniawan, A. (2017). Chronosequence Effect of Post Tin Mining Ponds to Metals Residu and Microecosystem Change. Omni-Akuatika, 13(1): 60-65.

Leal, P. L., M. V. Lopez, I. G. O. Prado., J. V. Santos., C. R. F. S. Soares., J. O. Siqueira., F. M. S. Moreiraa. (2016). Enrichment of arbuscular mycorrhizal fungi in a contaminated soil after rehabilitation. Braz J Microbiol. 47(4): 853-862.

Lingua, G., E. Bona., V. Todeschini., C. Cattaneo., F. Marsano., G. Berta., M. Cavaletto. (2012). Effects of Heavy Metals and Arbuscular Mycorrhiza on the Leaf Proteome of a Selected Poplar Clone: A Time Course Analysis. PLoS One. 7(2): e38662.

Liphadzi, M. S., K. B. Kirkham. (2005). Phytoremediation of soil contaminated with heavy metals: a technology for rehabilitation of the environment. South African Journal of Botany 71(1): 24-37.

Lone, R., S. Agarwal., K. K. Koul. (2014). Taxonomic Characteristic of Arbuscular Mycorrhizal Fungi-A Review. International Journal of Microbiological Research 5(3): 190-197.

Ma, Y., R. S. Oliveira., H. Freitas., C. Zhang. (2016). Biochemical and Molecular Mechanisms of Plant-Microbe-Metal Interactions: Relevance for Phytoremediation. Front Plant Sci. 7: 918.

Ministry of State for Population and Environment Republic of Indonesia and Dalhousie University Canada. (1992). Environmental Management in Indonesia. Report on Soil Quality Standards for Indonesia (interim report).

Ojuederie, O. B. and O. O. Babalola. (2017). Microbial and Plant-Assisted Bioremediation of Heavy Metal Polluted Environments: A Review. Int J Environ Res Public Health. 14: 1504.

Pereira, M. C., D. I. Rocha., T. G. R. Veloso., O. L. Pereira., D. M. T. Francino., R. M. S. A. Meira., M. C. M. Kasuya. (2015). Characterization of seed germination and protocorm development of Cyrtopodium glutiniferum (Orchidaceae) promoted by mycorrhizal fungi Epulorhiza spp. Acta Botanica Brasilica, 29(4): 567-574.

Rezvani, M., M. A. Ardakani., F. Rejali., F. Zaefarian., S. Teimouri., G. Noormohammadi., M. Miransari. (2015). Uptake of Heavy Metals by Mycorrhizal Barley (Hordeum vulgare L.). Journal of Plant Nutrition 38(6): 904-919.

Setiadi, Y and A. Setiawan. (2011). Study of Arbuscular Mycorrhizal Fungi status at Rehabilitation Post-Nickel Mining Area (Case study at PT INCO Tbk. Sorowako, South Sulawesi). Jurnal Silvikultur Tropika, 3(1): 88 - 95.

Shade, A., H. Peter., S. D. Allison., D. L. Baho., M. Berga., H. Burgmann., D. H. Huber., S. Langenheder., J. T. Lennon., J. B. H. Martiny., K. L. Matulich., T. M. Schmidt., J. Handelsman. (2012). Fundamentals of Microbial Community Resistance and Resilience. Front Microbiol, 3: 417.

Shanab, R. A. A., H. A. Ghozlan., K. M. Ghanem., H. A. Moawad. (2007). Heavy Metals in Soils and Plants from Various Metal Contaminated Sites in Egypt. Terrestrial and Aquatic Environmental Toxicology. 1(1):7-12.

Singh, R., N. Gautam., A. Mishra., R. Gupta. (2012). Heavy metals and living systems. Indian Journal of Pharmacology, 43(3): 246-253.

Singh, S. (2004). Effect of temperature on development of vesicular-arbuscular mycorrhizae in plants. Mycorrhiza News 16: 2-11.

Singh, S., P. Parihar., R. Singh., V. P. Singh., S. M. Prasad. (2016). Heavy Metal Tolerance in Plants: Role of Transcriptomics, Proteomics, Metabolomics, and Ionomics. Front. Plant Sci. 6:1143.

Tahat, M. M., K. Sijam. (2012). Mycorrhizal Fungi and Abiotic Environmental Conditions Relationship. Research Journal of Environmental Sciences, 6: 125-133. 
Tiwari, S. and C. Lata. (2018). Heavy Metal Stress, Signaling, and Tolerance Due to Plant-Associated Microbes: An Overview. Front. Plant Sci. 9: 452.

Toh, S. C., S. Lihan., B. C. W. Yong., B. R. Tiang., R. Abdullahi., R. Edward. (2018). Isolation and characterisation of Arbuscular mycorrhizal (AM) fungi spores from selected plant roots and their rhizosphere soil environment. Malaysian Journal of Microbiology, 14(4): 335-343.

Tommerup, I. C. (1983). Spore Dormancy in Vesicular-Arbuscular Mycorrhizal Fungi. Transactions of the British Mycological Society, 81(1): 37-45.

Trouvelot, S., Bonneau, L., Redecker, D., Tuinen, D., Adrian, M., Wipf, D. (2015). Arbuscular mycorrhiza symbiosis in viticulture: a review. Agronomy for Sustainable Development. 35(4): 1449-1467.

Upadhyaya, H., S. K. Panda., M. K. Bhattacharjee., S. Dutta. (2010). Role of Arbuscular Mycorrhiza in Heavy Metal Tolerance in Plants: Prospects for Phytoremidiation. Journal of Phytology. 2(7): 16-27.

Vaishaly, A. G., B. B. Mathew., N. B. Krishnamurthy., T. P. Krishnamurthy. (2015). Bioaccumulation of Heavy Metals by Fungi. International Journal of Environmental Chemistry \& Chromatography. 1(1): 15 - 21.

Yang, Y., Y. Liang., X. Han., T. Y. Chiu., Ghosh, A. H. Chen., M. Tang. (2016). The roles of arbuscular mycorrhizal fungi (AMF) in phytoremediation and tree-herb interactions in Pb contaminated soil. Sci Rep. 6: 20469.

Xuan Gong1*, Dong Qi Tian1 (2019). Study on the effect mechanism of Arbuscular Mycorrhiza on the absorption of heavy metal elements in soil by plants. IOP Conf. Series: Earth and Environmental Science, 267. 